\title{
Controls on Willow Cutting Survival in a Montane Riparian Area
}

\author{
Edward A. Gage ${ }^{1}$ and David J. Cooper ${ }^{2}$ \\ Authors are ${ }^{1}$ graduate research assistant, Graduate Degree Program in Ecology, and ${ }^{2}$ senior research scientist, \\ Department of Forest, Rangeland and Watershed Stewardship and Graduate Degree Program in Ecology, \\ Colorado State University, Fort Collins, CO 80523.
}

\begin{abstract}
To provide information to guide restoration of montane riparian willow communities, we investigated factors influencing the survival of prerooted and unrooted mountain willow (Salix monticola Bebb) cuttings in 2 degraded montane riparian areas in Rocky Mountain National Park, Colorado. We planted cuttings across a gradient of water table depths and soil textures and evaluated their survival using logistic regression analysis. Our results indicate that depth to groundwater was a critical factor influencing survival of both rooted and unrooted cuttings. We found that few cuttings $(7.8 \%$ rooted, $3.9 \%$ unrooted) survived where summer water table depths exceeded approximately $90 \mathrm{~cm}$. Soil texture was not a significant factor in our logistic models, potentially because of low silt and clay fractions in our plots. Rooted cuttings survived at a higher rate than unrooted cuttings after $1(55.8 \%$ vs. $36.5 \%, P<0.001)$ and $2(44.5 \%$ vs. $26.1 \%, P<0.001)$ years of growth. We conclude that, when combined with appropriate hydrologic data, the use of rooted cuttings represents an effective technique to restore and revegetate degraded montane riparian ecosystems.
\end{abstract}

\section{Resumen}

Para proveer información para guiar la restauración de las comunidades montanas ribereñas de "Willow" investigamos los factores que influyen en la sobrevivencia de esquejes pre-enraizados y sin enraizar de "Willow" (Salix monticola Bebb) en dos áreas ribereñas degradadas del Parque Nacional de las Montañas Rocallosas de Colorado. Plantamos los esquejes a lo largo de un gradiente de profundidad del manto freatico y texturas de suelo y evaluamos su sobrevivencia usando análisis de regresión logística. Nuestros resultados indican que la profundidad del manto freatico es un factor critico que influye en la sobrevivencia de los esquejes enraizados y sin enraizar. Encontramos que pocas estacas (7.8\% enraizado, $3.9 \%$ sin enraizar) sobrevivieron donde la profundidad del mato freatico en verano excede aproximadamente $\operatorname{los} 90 \mathrm{~cm}$. La textura de suelo no fue un factor significativo en nuestros modelos logísticos, probablemente debido a los bajos contenidos de limo y arcilla en nuestras parcelas. Los esquejes enraizados sobrevivieron a una tasa mayor que los esquejes sin enraizar, tanto 1 año $(55.8$ vs. $36.5 \%, p<0.001)$ como 2 años despues de plantados. Concluimos que si se combinan en forma apropiada con datos hidrológicos, el uso de esquejes enraizados representa una tecnica efectiva para restaurar y revegetar los ecosistemas ribereños montanos degradados.

Key Words: Salix monticola, water table depth, Rocky Mountain National Park, soil texture

\section{Introduction}

Preformed root primordia, found on the stems of many willow (Salix) species (Carlson 1938; Haissig 1970), represent an important adaptation to life in wetland and riparian environments. Willows may form adventitious roots or stems in saturated soils, allowing them to survive sediment burial from flood events, long periods of inundation, and even uprooting. In addition, stems broken during floods or cut by beaver may form asexual propagules that can establish and grow after being incorporated into beaver dams or dispersed by water (Cottrell 1995).

Willow stem cuttings have often been planted to stabilize stream banks (Carriere 1976; Shields et al 1995; Watson et al 1997), improve wildlife habitat (Densmore et al 1987), and restore wetlands and riparian zones (Densmore and Zasada 1978;

Funding was provided by National Park Service Water Resources Division and Rocky Mountain National Park grants to the junior author, and a student research grant to the senior author from the Society of Wetland Scientists.

Correspondence: David Cooper, Dept of Forest, Rangeland and Watershed Stewardship, Colorado State University, Fort Collins, C0 80523. Email: davidc@cnr.colostate.edu

Manuscript received 31 May 2003; manuscript accepted 16 April 2004.
Cooper and MacDonald 2000). However, there are few quantitative analyses of the factors influencing willow cutting survival, particularly along small-order montane streams in the interior western United States. In this study, we analyzed the survival of rooted and unrooted willow cuttings in relation to groundwater depth and soil texture with the goal of providing information that can be used to guide riparian restoration plantings.

\section{Materials and Methods}

\section{Study Area}

The study was conducted in Moraine Park (elevation $2480 \mathrm{~m}$, lat $40.35^{\circ} \mathrm{N}$, long $105.61^{\circ} \mathrm{W}$ ) and Horseshoe Park (elevation $2600 \mathrm{~m}$, lat $40.40^{\circ} \mathrm{N}$, long $105.62^{\circ} \mathrm{W}$ ), 2 broad, low-gradient alluvial valleys located on the east side of Rocky Mountain National Park (ROMO), Colorado. Soils in both sites are similar, primarily consisting of alluvial sand, gravel, and cobbles, although areas with loam soils occur associated with beaver ponds, abandoned channels, and backwaters. Mean annual precipitation in the study area is approximately $35 \mathrm{~cm}$, a significant portion of which comes during late-summer monsoon thunderstorms (Western Regional Climate Center, 1948- 
Table 1. Survival means (\%) and standard errors (in parentheses) for cuttings in the fall of 2000, and the spring and fall of 2001, for all plots from Horseshoe and Moraine Park combined. Test statistics are from paired t-tests $(n=39)$ of rooted and unrooted survival on each date.

\begin{tabular}{|c|c|c|c|c|c|c|c|}
\hline \multirow[b]{2}{*}{ Date } & \multicolumn{2}{|c|}{ Rooted } & \multicolumn{2}{|c|}{ Unrooted } & \multirow[b]{2}{*}{$t$} & \multirow[b]{2}{*}{$d f$} & \multirow[b]{2}{*}{$P$} \\
\hline & mean & SE & mean & SE & & & \\
\hline Sep. 2000 & 55.8 & (5.9) & 36.5 & (6.1) & 3.64 & 38 & $<0.001$ \\
\hline Jun. 2001 & 48.6 & (5.3) & 28.6 & $(4.8)$ & 4.52 & 38 & $<0.001$ \\
\hline Sep. 2001 & 44.5 & $(5.2)$ & 26.1 & (4.9) & 3.87 & 38 & $<0.001$ \\
\hline
\end{tabular}

2001 data). Vegetation at both sites is composed of dry and wet meadows and riparian shrub communities dominated by mountain willow (Salix monticola Bebb), Geyer willow ( $S$. geyeriana Anderss.), planeleaf willow (S. planifolia Pursh), and river birch (Betula fontinalis Sarg.). The spatial extent and condition of willow communities in portions of Rocky Mountain National Park has declined during the latter half of the 20th century due in part to heavy browsing by an increasing elk (Cervus elaphus) population (Peinetti et al 2002), and Park managers are interested in possible restoration of degraded sites.

\section{Experimental Design}

In early May 2000, before leaf out, we collected 500 stem cuttings, each $30 \mathrm{~cm}$ long and $8-12 \mathrm{~mm}$ in diameter, from the interior of 10 mountain willow plants located in tall-stature, lightly-browsed willow stands in western Moraine and Horseshoe Parks. The cutting length was selected to minimize impacts to donor willows, allow for ease of collection and planting, and minimize the space required for cutting storage and prerooting treatments. Two hundred fifteen cuttings were randomly selected and planted, with $20 \mathrm{~cm}$ or two-thirds of the stem below the soil surface, into $6.4 \times 30.5 \mathrm{~cm} \mathrm{Zipset}{ }^{\circledR}$ planting containers (Monarch Manufacturing Company, Salida, CO) filled with a 50:50 mix of topsoil and sand from the ROMO nursery facilities. The containers were immersed in $20 \mathrm{~cm}$ of water for 6 weeks at the ROMO nursery to induce rooting. Unrooted cuttings were stored in large plastic tubs filled with water placed outside at the ROMO nursery until planting. At the time of planting, cuttings exhibited limited adventitious root formation. No rooting hormones were used with either treatment.

In June 2000, we established 24 plots at the full range of elevations above the active stream channel in the Big Thompson River floodplain in Moraine Park and 15 plots along the Fall River in Horseshoe Park. Soils in plots were coarsetextured alluvial sand and gravel with varying amounts of cobble. We planted 7 unrooted and, because of a limited supply, 5 rooted cuttings into each plot and placed small exclosures constructed from heavy-gauge wire fencing over cuttings to prevent elk browsing. Rooted cuttings were removed from Zipset ${ }^{\circledR}$ containers immediately before planting and all cuttings were planted so that $20 \mathrm{~cm}$ of the cutting were below the ground surface. Groundwater or surface water depth was measured biweekly during the 2000 and 2001 growing seasons in either a fully slotted polyvinyl chloride monitoring well or a staff gauge installed adjacent to each plot. Soil samples were collected from each plot for soil texture analysis using the

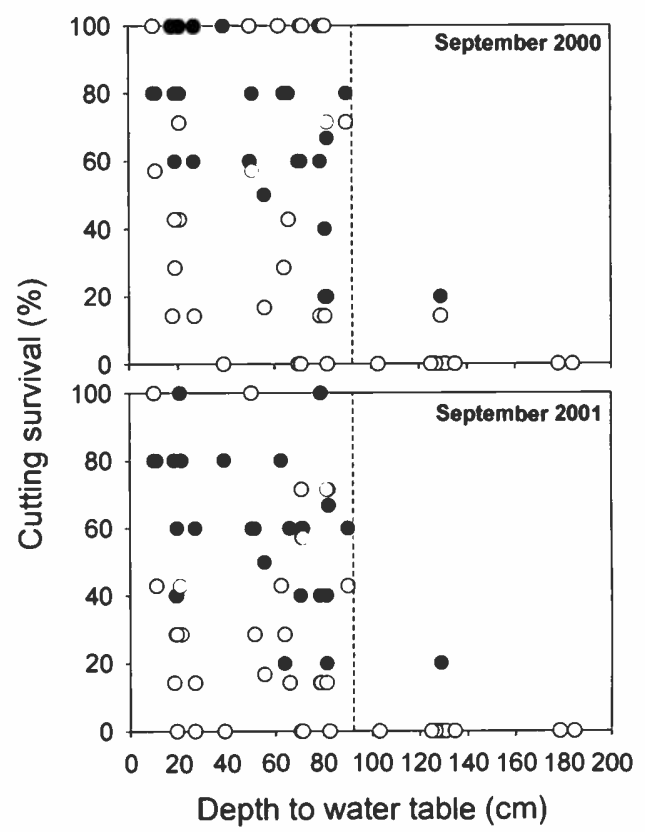

Figure 1. Mean survivorship for rooted ( $\bullet$ ) and unrooted (o) cuttings after 1 (top) and 2 (bottom) growing seasons in Moraine and Horseshoe Park plots in relation to mid-August 2000 water table depth. Dashed line represents approximate water table depth threshold for cutting survival.

hydrometer method (Gee and Bauder 1986). We tallied the number of live cuttings in each plot in September of 2000, and again in June and September of 2001.

\section{Data Analysis}

To identify factors affecting planting success, we used stepwise logistic regression to model the influence of water table depth and the percentage of silt and clay in soils on cutting survivorship (Proc LOGISTIC, SAS Institute 2000). Although representative water table depths from the early, middle, and late portions of the growing season were evaluated initially, there was considerable collinearity among water table depths at different dates. Therefore, we selected the water table depths from late August, which had the highest statistical significance in initial analyses and represented the approximate low point in well hydrographs, for use in the final analysis. Because clay fractions in study area soils are low, we used the combined percentage of silt and clay in our logistic regression. All first-, second-, and third-order polynomials were evaluated and only variables with a $P \leq 0.05$ significance level or those required to maintain model hierarchy were retained in the final model. Separate analyses examined rooted and unrooted cutting survival after 1 and 2 seasons. Overall model fit was assessed using the chi-square likelihood ratio statistic and McFadden's $\rho^{2}$, an analogue to the coefficient of determination in linear regression. Paired $t$ tests were used to compare rooted and unrooted cutting survival on different dates.

\section{Results}

Rooted cutting survival was significantly greater than unrooted cuttings after the first summer $(55.8 \%$ vs. $36.5 \%)$, the first 
Table 2. Results of logistic regression analysis of rooted and unrooted cutting survival after 1 and 2 growing seasons. The variable WTD in logistic models refers to mid-August 2000 water table depth, and the term M represents the probability of mortality.

\begin{tabular}{|c|c|c|c|c|c|}
\hline Type & Logistic model & $\chi^{2}$ & $d f$ & $P>\chi^{2}$ & $\rho^{2}$ \\
\hline \multicolumn{6}{|l|}{ Sep 00} \\
\hline Rooted & Logit(M) $=-1.01-0.03[$ WTD $]+0.0005[W T D]^{2}$ & 85.3 & 2 & $<0.001$ & 0.36 \\
\hline Unrooted & Logit(M) $=-2.16+0.18[$ WTD $]-0.004[\text { WTD }]^{2}+0.00002[W T D]^{3}$ & 70.3 & 3 & $<0.001$ & 0.22 \\
\hline \multicolumn{6}{|l|}{ Sep 01} \\
\hline Rooted & Logit(M) $=-0.64-0.02[\mathrm{WTD}]+0.0004[\mathrm{WTD}]^{2}$ & 63.9 & 2 & $<0.001$ & 0.28 \\
\hline Unrooted & Logit(M) $=-2.94+0.33[$ WTD $]-0.007[W T D]^{2}+0.00004[W T D]^{3}$ & 53.0 & 3 & $<0.001$ & 0.17 \\
\hline
\end{tabular}

winter $(48.6 \%$ vs. $28.6 \%)$, and the second summer $(44.5 \%$ vs. $26.1 \%$ ) (Table 1). There was a trend in both rooted and unrooted cuttings toward lower survival from September 2000 to September 2001. After 1 growing season, few cuttings $(7.8 \%$ rooted, $3.9 \%$ unrooted) survived where the late-summer water table was $>90 \mathrm{~cm}$ below the ground surface (Fig. 1). The importance of water table depth on cutting survival was confirmed in our logistic regression models. Mid-August water table depths along with several polynomial terms were significant in the selected models for both rooted and unrooted cuttings (Table 2). Late-summer water table depths varied widely among plots, from approximately $10 \mathrm{~cm}$ below the ground surface to over $180 \mathrm{~cm}$. In contrast, the combined percentage of silt and clay fractions was relatively low in all plots, ranging from $5.1 \%$ to $19.1 \%$, and soil texture was not a significant predictor of cutting survival in any of the selected models.

\section{Discussion}

Our results indicate that water table depth exerted a significant control on willow stem cutting survival. Few rooted or unrooted cuttings survived where the late-summer water table was more than $90 \mathrm{~cm}$ below the soil surface, although survival was highly variable among sites with water table depths less than $90 \mathrm{~cm}$. On the basis of our original planting depth of 20 $\mathrm{cm}$, our results suggest that willow roots can grow to reach the capillary fringe above a $90-\mathrm{cm}$-deep water table, but deeper water tables lead to high mortality using our methods. The difference between original planting and water table depths is key to proper interpretation of our results; it is likely that higher cutting survival would have occurred in sites with deeper water tables had longer cuttings been used. However, longer cuttings require more time and space to process and cause greater impacts to donor populations, hence our choice of the 30-cm length.

Qualitatively, our findings are similar to those reported by Conroy and Svejcar (1991), who found that the highest survival $(\sim 73 \%)$ of unrooted Geyer willow cuttings occurred in locations with shallow water tables $(\sim 27 \mathrm{~cm})$, whereas the lowest survival $(\sim 7 \%)$ occurred in sites with deep water tables $(\sim 126 \mathrm{~cm})$. Late-summer water table depth likely affects cutting survival by directly controlling water availability during hot summer months. Capillary rise from the water table in finetextured soils may also influence planting success in some areas, but in our study, soil texture did not have a statistically significant influence on cutting survival. This is likely due to the coarse-textured soils found in all of our plots, which have a relatively low water-holding capacity and capillary fringe. Early root formation may also affect willow cutting survival (Schaff et al 2002). The higher survival of rooted versus unrooted cuttings, particularly in plots with deeper water tables, suggests that the formation of a sufficiently deep root system strongly influences the ability of cuttings to tolerate dry soil conditions late in the summer and that prerooted cuttings have faster root development once planted.

Prolonged inundation has also been reported to reduce willow cutting growth and survival (Talbot et al 1987; Pezeshki et al 1998). However, none of our study plots was inundated for more than 1 week, and we observed no decrease in willow survival in plots with shallow water tables. Flooding along snowmelt-dominated rivers in the interior western United States is typically of short duration and may not inundate sites long enough to cause significant mortality. However, prolonged inundation does occur around the margins of beaver ponds, but, by raising local water tables (Gurnell 1998), beaver dams may increase the total area suitable for willow planting survival.

Pronounced differences in rooting potential among willow species has been reported (Talbot et al 1987; Cottrell 1993). The relatively high survival of mountain willow cuttings in our study suggests that this species is well suited for riparian restoration projects, although ecologically similar species, such as Geyer willow, Drummond willow ( $S$. drummondiana Barratt), and Booth willow (S. boothii Dorn), might also be successfully used. Because of the higher survival rate associated with prerooted cuttings, we recommend their use on sites where high survival rates and rapid plant establishment are desired. Since water table depth has such a significant influence on willow cutting survival, we also recommend that site hydrology be analyzed using groundwater monitoring wells for at least 1 full summer before planting. These data can be used to identify areas with water table depths suitable for the planting of willow cuttings and to suggest appropriate methods such as increasing cutting length or using prerooting treatments that may increase the probability of planting success.

\section{Literature Cited}

Carlson, M. C. 1938. The formation of nodal adventitious roots in Salix cordata. American Journal of Botany 25:721-725.

CARRIERE, B. D. 1976. Streambank stabilization with willows. Agricultural Research $24: 11$. 
Conroy, S. D., and T. J. SvejCaR. 1991. Willow planting success as influenced by site factors and cattle grazing in Northeastern California. Journal of Range Management 44:59-63.

COOPER, D. J., AND L. H. MACDONALD. 2000. Restoring the vegetation of mined peatlands in the southern Rocky Mountains of Colorado, U.S.A. Restoration Ecology 8:103-111.

CottrelL, T. R. 1993. The comparative ecology of Salix planifolia and Salix monticola in Rocky Mountain National Park [PhD thesis]. Fort Collins, CO: Colorado State University. 230 p.

CottrelL, T. R. 1995. Willow colonization of Rocky Mountain mires. Canadian Journal of Forestry Research 25:215-222.

Densmore, R., AND J. C. ZASADA. 1978. Rooting potential of Alaskan willow cuttings. Canadian Journal of Forestry Research 8:477-479.

Densmore, R. V., B. J. Nelland, J. C. Zasada, and M. A. Masters. 1987. Planting willow for moose habitat restoration on the North Slope of Alaska, USA. Arctic and Alpine Research 19:537-543.

Gee, G. W., and J. W. Bauder. 1986. Particle-size analysis. In: A. Klute [ed.]. Methods of soil analysis, part 1. Physical and mineralogical methods. Madison, WI: American Society of Agronomy. p 383-411.
GurnelL, A. M. 1998. The hydrogeomorphological effects of beaver dam-building activity. Progress in Physical Geography 22:167-189.

HaISSIG, B. W. 1970. Preformed adventitious root initiation in brittle willows grown in a controlled environment. Canadian Journal of Botany 48:2309-2312.

Peinett, H. R., M. A. Kalkhan, and M. B. Coughenour. 2002. Long-term changes in willow spatial distribution on the elk winter range of Rocky Mountain National Park (USA). Landscape Ecology 17:341-354.

Pezeshi, S. R., P. H. Anderson, and F. D. Shields, JR. 1998. Effects of soil moisture regimes on growth and survival of black willow (Salix nigra) posts (cuttings). Wetlands 18:460-470.

SChaff, S. D., S. R. PezeShKI, AND F. D. Shields. 2002. Effects of pre-planting soaking on growth and survival of black willow cuttings. Restoration Ecology 10:267-274.

Shields, F. D., S. S. KNIGHT, AND C. M. CoOper. 1995. Rehabilitation of watersheds with incising channels. Water Resources Bulletin 31:971-982.

Talbot, R. J., J. R. Etherington, and J. A. Bryant. 1987. Comparative studies of plant growth and distribution in relation to waterlogging. New Phytologist 105:563-574.

Watson, C. C., S. R. ABt, And D. Derrick. 1997. Willow posts bank stabilization. Journal of the American Water Resources Association 33:293-300. 